\title{
Sensory and Mass Spectrometric Analysis of the Peptidic Fraction Lower Than One Thousand Daltons in Manchego Cheese
}

\author{
J. Á. Gómez-Ruiz, ${ }^{1}$ G. Taborda, ${ }^{2}$ L. Amigo, M. Ramos, and E. Molina ${ }^{3}$ \\ Instituto de Fermentaciones Industriales, Consejo Superior de Investigaciones Científicas (CSIC), C/ Juan de la Cierva, 3, 28006 Madrid, Spain
}

\begin{abstract}
A total of 107 different peptides, all derived from $\alpha_{\mathrm{S}^{-}}, \alpha_{\mathrm{S} 2^{-}}$, and $\beta$-casein, were identified in different fractions of artisan or industrial Manchego cheese at 4 and 8 mo of ripening, and their sequences were examined. Most of these peptides are described for the first time in Manchego cheese. Taste characteristics (umami and bitter) were assigned based on their AA sequence and the position of these AA within the sequence. The umami taste was predominant in all fractions analyzed by the panelists, and the peptides EQEEL, QEEL, and EINEL, containing a high number of glutamic residues, were found within the fractions. However, in several fractions described as having umami characteristics, no peptides responsible for this taste were detected. Therefore, compounds other than peptides seem to be involved in the umami properties of water-soluble extracts lower than 1,000 Da of Manchego cheese.
\end{abstract}

Key words: cheese taste, mass spectrometry, sensory analysis, umami

\section{INTRODUCTION}

Manchego cheese is the main Spanish variety having a protected denomination of origin. It has a very complex and characteristic flavor. Compounds that contribute to cheese flavor are mainly produced as a consequence of the biochemical changes during ripening. Most research on Manchego cheese flavor has been focused on its volatile components (e.g., González-Viñas et al., 2001; Fernández-García et al., 2002; GómezRuiz et al., 2002a). In addition, cheese taste is one of the most important organoleptic attributes, and the

\footnotetext{
Received May 8, 2007.

Accepted June 4, 2007.

${ }^{1}$ Current address: European Commission-Joint Research Centre Institute for Reference Materials and Measurements (IRMM), Food Safety and Quality Unit, Retieseweg 111, B-2440 Geel, Belgium.

${ }^{2}$ Current address: Universidad de Caldas, Facultad de Ciencias Exactas y Naturales, Departamento de Química, Calle 65 n²6-10 Manizales (Caldas), Colombia.

${ }^{3}$ Corresponding author: e.molina@ifi.csic.es
}

correct balance of sapid compounds is essential to cheese quality (McSweeney, 1997). Engels and Visser (1994) and Taborda et al. (2003) have analyzed watersoluble extracts (WSE) of different types of cheeses and suggested that low molecular weight compounds such as small peptides and AA, short-chain fatty acids, volatile compounds, and organic acids and ions are responsible for the basic taste of cheeses. Molina et al. (1999) fractionated the WSE of cheese made from milk of different species, and differences in the taste were established depending on the origin of the milk.

Recently, studies on the relationship between the particular organoleptic characteristics of Manchego cheese and the presence of small peptides, AA, shortchain fatty acids, volatile compounds, other organic acids and ions in the different fractions of WSE lower than $1,000 \mathrm{Da}$ (WSE $<1,000 \mathrm{Da}$ ) have been carried out in our laboratory (Taborda, 2001). Volatile compounds have been related to the flavor and small peptides and AA to the taste. However, no peptides have been identified in the different fractions. Identification of peptides in cheeses is an intensive and difficult task; nevertheless, liquid chromatography-tandem mass spectrometry (MS/MS) allows the identification and sequencing of a large number of peptides in a relatively short analysis time. Several configurations of mass spectrometers now provide MS/MS data with sufficient mass accuracy to deduce peptide sequences of enzymatically digested proteins from low-energy collisionally induced MS/MS spectra (Careri and Mangia, 2003). High-performance liquid chromatography-MS/ MS has been used by Gómez-Ruiz et al. (2002b, 2004, 2006) to identify the bioactive peptides with demonstrated angiotensin I-converting enzyme inhibitory activity in different types of cheeses.

Peptides have a wide range of tastes, and their importance to the sensory perception of foods has been recognized. However, not many peptides have been identified and related to the taste of cheese (Polo et al., 2000). Despite some claims, the real impact of small peptides on the taste of cheese has not been clearly demonstrated. The objectives of this study were to identify taste-active peptides by HPLC-MS/MS in dif- 
ferent fractions of WSE of raw and pasteurized Manchego cheeses at 2 different stages of ripening, and to relate their presence to the sensory characteristics of these fractions, as previously evaluated by expert panelists.

\section{MATERIALS AND METHODS}

\section{Samples of Cheese}

Protected denomination of origin Manchego cheese samples (artisan and industrial), at 4 and $8 \mathrm{mo}$ of ripening, were purchased in the local supermarket. The samples were analyzed in duplicate.

\section{Isolation and Fractionation of the WSE $<1,000 \mathrm{Da}$}

The WSE $<1,000$ Da was obtained following the method described by Salles et al. (1995). Briefly, $50 \mathrm{~g}$ of cheese was homogenized with $100 \mathrm{~mL}$ of water and held in a water bath at $40^{\circ} \mathrm{C}$ for $1 \mathrm{~h}$. After centrifugation $\left(3,800 \times g ; 20^{\circ} \mathrm{C}, 30 \mathrm{~min}\right)$, the supernatant was filtered and ultracentrifuged $\left(100,000 \times g ; 20^{\circ} \mathrm{C}, 30\right.$ min). The resultant supernatant (WSE) was UF at $4^{\circ} \mathrm{C}$ in an ultrafiltration cell with a 1,000 -Da cutoff cellulose membrane (YM1, Dia-Flo, Millipore, Bedford, MA) in an ultrafiltration cell (Diaflo, Millipore) to obtain the WSE $<1,000 \mathrm{Da}$. The WSE $<1,000 \mathrm{Da}$ was then fractionated by gel-permeation chromatography (GPC) with a Superformance Sephadex G10 column $(1.6 \times 60 \mathrm{~cm}$, Pharmacia, Uppsala, Sweden $)$ with manual injection. Elution was done with Milli-Q water (Millipore) to allow sensory evaluation at a constant flow of $2 \mathrm{~mL} / \mathrm{min}$. The detection was carried out at $280 \mathrm{~nm}$ in a 2138 Uvicords detector (LKB, Uppsala, Sweden). Five fractions were automatically collected. Two milliliters of each fraction was lyophilized, redissolved in $200 \mu \mathrm{L}$ of water:trifluoroacetic acid (TFA) (1,000:0.37), and sonicated for $30 \mathrm{~min}$ before analysis by reversed-phase (RP) HPLC-MS/MS.

\section{RP-HPLC-MS/MS Analysis}

The 5 fractions obtained from the WSE $<1,000 \mathrm{Da}$ of the different cheeses were analyzed by analytical RP-HPLC-MS/MS with a Hi-Pore $\mathrm{C}_{18}$ column $(250 \times$ $4.6 \mathrm{~mm}, 5 \mu \mathrm{m}$ particle size, Bio-Rad Laboratories, Richmond, CA) in an HP Agilent 1100 system (Agilent Technologies, Santa Clara, CA) connected to an Esquire-LC quadrupole ion trap (Bruker Daltonik GmbH, Bremen, Germany). The HPLC system was equipped with a quaternary pump (Agilent Series 1100 ) and a variable wavelength detector (Agilent Series 1100) in combination with an autosampler (Agilent Series 1000). Data were processed by using
ChemStation for LC 3D Systems (Agilent Technologies). The injection volume was $100 \mu \mathrm{L}$ and the samples were eluted at a flow rate of $0.8 \mathrm{~mL} / \mathrm{min}$. Solvent A was a mixture of water:TFA (1,000:0.37) and solvent B was a mixture of acetonitrile:water:TFA (800:200:0.27). A step gradient system of water and acetonitrile was used as the mobile phase: solvent A (100\%) for $5 \mathrm{~min}$, then a linear gradient to $40 \%$ solvent $\mathrm{B}$ in $60 \mathrm{~min}$, and from 40 to $70 \%$ solvent $\mathrm{B}$ in $5 \mathrm{~min}$. The absorbance was monitored at $214 \mathrm{~nm}$. The flow $(0.8 \mathrm{~mL} / \mathrm{min})$ was split postcolumn by placing a Tpiece (Valco, Houston, TX) connected with a 75- $\mu \mathrm{m}$ i.d. polyetheretherketone (PEEK) outlet tube of an adjusted length to give approximately $20 \mu \mathrm{L} / \mathrm{min}$ of flow directed into the mass spectrometer via the electrospray interface. The mass spectrometer used nitrogen as the nebulizing and drying gas and operated with an estimated helium pressure of $5 \times 10^{-3}$ bar. The capillary was held at $4 \mathrm{kV}$. By using electrospray ionization in the positive ion mode, mass spectra were acquired from $\mathrm{m} / z 100$ to 900 . Approximately 15 spectra were averaged in the MS analyses, and approximately 5 spectra were analyzed in the multiple $\mathrm{MS}^{\mathrm{n}}$ analyses. The signal threshold to perform auto $\mathrm{MS}^{\mathrm{n}}$ analyses was 5,000, and the precursor ions were isolated within a range of $4.0 \mathrm{~m} / z$ and fragmented with a voltage increase from 0.35 to $1.4 \mathrm{~V}$. Automation of data processing was achieved by using DataAnalysis (version 3.0, Bruker Daltonik) and the software package Biotools (version 2.1, Bruker Daltonik).

\section{Taste of the Identified Peptides}

The taste characteristics of the identified peptides were assigned depending on the AA and their positions in the sequence. For the umami taste, all the sequences suggested by Roudot-Algaron (1996) and Maehashi et al. (1999) as capable of giving such a taste were searched for within our identified peptides in Manchego cheese. Ten peptides with umami taste were found: PSE, RKE, SAEQK, ENINEL, INEL, EQEEL, QEEL, NVVGET, VVGET, LEQL.

Bitter peptides were selected to look for the sequences capable of giving such a taste, as suggested Kim and Li-Chan (2006). Thirteen peptides with the sequences PPF and PFP (which showed high bitterness values in the work of the above-mentioned authors) were considered in this study: VVAPFP, VVAPFPE, VVAPFPEV, VAPFP, VAPFPE, APFPE, VPPFL, PFPKY, GPVRGPFP, VRGPFP, RGPFPI, GPFP, GPFPI.

\section{Sensory Analysis}

A panel of 6 experienced panelists ( 5 women and 1 man, ages 25 to 50) were selected from 12 participating 
Table 1. Identified peptides in the permeate $<1,000 \mathrm{Da}$ of gel-permeation chromatographic fractions of artisan and industrial Manchego cheeses at 4 and 8 mo of age

\begin{tabular}{|c|c|c|c|c|c|}
\hline Item & Sequence & Protein fragment & $\begin{array}{l}\text { Observed } \\
\text { mass }\end{array}$ & $\begin{array}{l}\text { Calculated } \\
\text { mass }\end{array}$ & Fraction $^{1}$ \\
\hline \multicolumn{6}{|c|}{$\alpha_{\mathrm{S} 1}-\mathrm{CN}$} \\
\hline 1. & RPK & $\alpha_{\mathrm{S} 1}-\mathrm{CN}(1-3)$ & 399.2 & 399.267 & $4,6,7$ \\
\hline 2. & RPKHPIK & $\alpha_{\mathrm{S} 1}-\mathrm{CN}(1-7)$ & 874.4 & 874.557 & 6 \\
\hline 3. & PKHP & $\alpha_{\mathrm{S} 1}-\mathrm{CN}(2-5)$ & 477.3 & 477.277 & 8 \\
\hline 4. & HPIK & $\alpha_{\mathrm{S} 1}-\mathrm{CN}(4-7)$ & 493.2 & 493.309 & $2,4,6,7,8,9$ \\
\hline 5. & IKHQ & $\alpha_{\mathrm{S} 1}-\mathrm{CN}(6-9)$ & 524.2 & 524.314 & 8 \\
\hline 6. & HQGL & $\alpha_{\mathrm{S} 1}-\mathrm{CN}(8-11)$ & 453.2 & 453.241 & $4,7,8,9,10$ \\
\hline 7. & VLNEN & $\alpha_{\mathrm{S} 1}-\mathrm{CN}(15-19)$ & 587.2 & 587.299 & 3 \\
\hline 8. & VLNENL & $\alpha_{\mathrm{S} 1}-\mathrm{CN}(15-20)$ & 700.3 & 700.383 & 1,3 \\
\hline 9. & LNEN & $\alpha_{\mathrm{S} 1}-\mathrm{CN}(16-19)$ & 488.2 & 488.233 & 1,3 \\
\hline 10. & LNENL & $\alpha_{\mathrm{S} 1}-\mathrm{CN}(16-20)$ & 601.3 & 601.314 & $1,3,8$ \\
\hline 11. & NLLR & $\alpha_{\mathrm{S} 1}-\mathrm{CN}(19-22)$ & 514.4 & 514.333 & 4,7 \\
\hline 12. & LLR & $\alpha_{\mathrm{S} 1}-\mathrm{CN}(20-22) ; \alpha_{\mathrm{S} 1}-\mathrm{CN}(98-100)$ & 400.3 & 400.287 & 4 \\
\hline 13. & LLRF & $\alpha_{\mathrm{S} 1}-\mathrm{CN}(20-23)$ & 547.4 & 547.356 & 4 \\
\hline 14. & VVAP & $\alpha_{\mathrm{S} 1}-\mathrm{CN}(24-27)$ & 384.2 & 384.245 & $3,4,6,7,8$ \\
\hline 15. & VVAPFP & $\alpha_{\mathrm{S} 1}-\mathrm{CN}(24-29)$ & 628.3 & 628.366 & 3,4 \\
\hline 16. & VVAPFPE & $\alpha_{\mathrm{S} 1}-\mathrm{CN}(24-30)$ & 757.3 & 757.408 & $1,3,6,7,8$ \\
\hline 17. & VVAPFPEV & $\alpha_{\mathrm{S} 1}-\mathrm{CN}(24-31)$ & 856.4 & 856.477 & 3 \\
\hline 18. & VAPFP & $\alpha_{\mathrm{S} 1}-\mathrm{CN}(25-29)$ & 529.2 & 529.297 & 4 \\
\hline 19. & VAPFPE & $\alpha_{\mathrm{S} 1}-\mathrm{CN}(25-30)$ & 658.3 & 658.343 & 1,3 \\
\hline 20. & APFPE & $\alpha_{\mathrm{S} 1}-\mathrm{CN}(26-30)$ & 559.3 & 559.271 & $1,3,4,7,8$ \\
\hline 21. & FRKE & $\alpha_{\mathrm{S} 1}-\mathrm{CN}(32-35)$ & 578.3 & 578.325 & 4 \\
\hline 22. & RKE & $\alpha_{\mathrm{S} 1}-\mathrm{CN}(33-35) ; \alpha_{\mathrm{S} 2}-\mathrm{CN}(32-34)$ & 431.2 & 431.257 & 6 \\
\hline 23. & RKEN & $\alpha_{\mathrm{S} 1}-\mathrm{CN}(33-36)$ & 545.3 & 545.299 & 6 \\
\hline 24. & KENIN & $\alpha_{\mathrm{S} 1}-\mathrm{CN}(34-38)$ & 616.3 & 616.325 & 1,3 \\
\hline 25. & ENINEL & $\alpha_{\mathrm{S} 1}-\mathrm{CN}(35-40)$ & 730.3 & 730.357 & 1,3 \\
\hline 26. & NINE & $\alpha_{\mathrm{S} 1}-\mathrm{CN}(36-39)$ & 488.2 & 488.233 & 1,3 \\
\hline 27. & INEL/LNEI & $\alpha_{\mathrm{S} 1}-\mathrm{CN}(37-40) ; \alpha_{\mathrm{S} 2}-\mathrm{CN}(83-86)$ & 487.3 & 487.271 & $1,3,4,6,8$ \\
\hline 28. & SIEDQ & $\alpha_{\mathrm{S} 1}-\mathrm{CN}(48-52)$ & 590.2 & 590.262 & 8 \\
\hline 29. & IEDQ & $\alpha_{\mathrm{S} 1}-\mathrm{CN}(49-52)$ & 503.2 & 503.233 & 6 \\
\hline 30. & IEDQA & $\alpha_{\mathrm{S} 1}-\mathrm{CN}(49-53)$ & 574.3 & 574.267 & 8 \\
\hline 31. & EDAK & $\alpha_{\mathrm{S} 1}-\mathrm{CN}(55-58)$ & 461.2 & 461.219 & 1 \\
\hline 32. & EDAKQ & $\alpha_{\mathrm{S} 1}-\mathrm{CN}(55-59)$ & 589.3 & 589.278 & $1,3,6$ \\
\hline 33. & DAKQM & $\alpha_{\mathrm{S} 1}-\mathrm{CN}(56-60)$ & 591.2 & 591.276 & 3,8 \\
\hline 34. & AKQMK & $\alpha_{\mathrm{S} 1}-\mathrm{CN}(57-61)$ & 604.3 & 604.344 & 7 \\
\hline 35. & SAEQK & $\alpha_{\mathrm{S} 1}-\mathrm{CN}(75-79)$ & 561.2 & 561.283 & 6 \\
\hline 36. & PSE & $\alpha_{\mathrm{S} 1}-\mathrm{CN}(87-89)$ & 331.2 & 331.145 & 1,3 \\
\hline 37. & SERY & $\alpha_{\mathrm{S} 1}-\mathrm{CN}(88-91)$ & 553.2 & 553.257 & 9 \\
\hline 38. & ERYL & $\alpha_{\mathrm{S} 1}-\mathrm{CN}(89-92)$ & 579.3 & 579.309 & $5,7,9,10$ \\
\hline 39. & LEQL/NKKI & $\alpha_{\mathrm{S} 1}-\mathrm{CN}(95-98) ; \beta-\mathrm{CN}(27-30)$ & 501.3 & 501.287 & 3,6 \\
\hline 40. & LLRL & $\alpha_{\mathrm{S} 1}-\mathrm{CN}(98-101)$ & 513.4 & 513.371 & $4,7,9$ \\
\hline 41. & LRL & $\alpha_{\mathrm{S} 1}-\mathrm{CN}(99-101)$ & 400.4 & 400.287 & 7 \\
\hline 42. & LKKY & $\alpha_{\mathrm{S} 1}-\mathrm{CN}(101-104)$ & 550.4 & 550.355 & 4 \\
\hline 43. & KKYN & $\alpha_{\mathrm{S} 1}-\mathrm{CN}(102-105)$ & 551.3 & 551.314 & 7 \\
\hline 44. & NVPQL & $\alpha_{\mathrm{S} 1}-\mathrm{CN}(105-109)$ & 569.3 & 569.325 & 3 \\
\hline 45. & VPQL & $\alpha_{\mathrm{S} 1}-\mathrm{CN}(106-109)$ & 455.3 & 455.282 & 3,4 \\
\hline 46. & PQL & $\alpha_{\mathrm{S} 1}-\mathrm{CN}(107-109)$ & 356.3 & 356.213 & 7 \\
\hline 47. & EIVPK & $\alpha_{\mathrm{S} 1}-\mathrm{CN}(110-114)$ & 584.4 & 584.361 & $1,3,4,6,7,8,9$ \\
\hline 48. & IVPK & $\alpha_{\mathrm{S} 1}-\mathrm{CN}(111-114)$ & 455.3 & 455.318 & $4,7,8$ \\
\hline 49. & $\mathrm{AHQ}$ & $\alpha_{\mathrm{S} 1}-\mathrm{CN}(129-131)$ & 354.2 & 354.172 & 4,8 \\
\hline 50. & LPL & $\begin{array}{l}\alpha_{\mathrm{S} 1} \mathrm{CN}(159-161) ; \beta-\mathrm{CN}(75-77) ; \\
\beta-\mathrm{CN}(135-137) ; \beta-\mathrm{CN}(137-139)\end{array}$ & 341.2 & 341.239 & 4 \\
\hline \multicolumn{6}{|c|}{$\alpha_{\mathrm{S} 2}-\mathrm{CN}$} \\
\hline 51. & EKNM & $\alpha_{\mathrm{S}^{2}} \mathrm{CN}(24-27)$ & 520.2 & 520.239 & 1,3 \\
\hline 52. & AIHP & $\alpha_{\mathrm{S}_{2}-\mathrm{CN}}(28-31)$ & 436.3 & 436.251 & 4 \\
\hline 53. & AIHPR & $\alpha_{\mathrm{S}^{2}}-\mathrm{CN}(28-32)$ & 592.4 & 592.352 & 4,7 \\
\hline 54. & IHPR & $\alpha_{\mathrm{S}_{2}-\mathrm{CN}}(29-32)$ & 521.3 & 521.315 & 4 \\
\hline 55. & PRKE & $\alpha_{\mathrm{S}^{2}} \mathrm{CN}(31-34)$ & 528.3 & 528.309 & $3,4,7$ \\
\hline 56. & VVRN & $\alpha_{\mathrm{S}^{2}}-\mathrm{CN}(44-47)$ & 486.4 & 486.299 & $4,7,8$ \\
\hline 57. & VRN & $\alpha_{\mathrm{S}^{2}} \mathrm{CN}(45-47)$ & 387.3 & 387.233 & 7 \\
\hline 58. & PQY & $\alpha_{\mathrm{S} 2}-\mathrm{CN}(94-96) ; \alpha_{\mathrm{S} 2}-\mathrm{CN}(178-180)$ & 406.2 & 406.193 & 7 \\
\hline 59. & LKKI & $\alpha_{\mathrm{S} 2}-\mathrm{CN}(165-168)$ & 500.2 & 500.376 & 3 \\
\hline 60. & VRYL & $\alpha_{\mathrm{S} 2}-\mathrm{CN}(205-208)$ & 549.3 & 549.335 & 4,5 \\
\hline
\end{tabular}


Table 1 (Continued). Identified peptides in the permeate $<1,000 \mathrm{Da}$ of gel-permeation chromatographic fractions of artisan and industrial Manchego cheeses at 4 and 8 mo of age

\begin{tabular}{|c|c|c|c|c|c|}
\hline Item & Sequence & Protein fragment & $\begin{array}{l}\text { Observed } \\
\text { mass }\end{array}$ & $\begin{array}{l}\text { Calculated } \\
\text { mass }\end{array}$ & Fraction $^{1}$ \\
\hline \multicolumn{6}{|l|}{$\beta-\mathrm{CN}$} \\
\hline 61. & EQEE & $\beta-\mathrm{CN}(2-5)$ & 533.2 & 533.204 & 1 \\
\hline 62. & EQEEL & $\beta-\mathrm{CN}(2-6)$ & 646.3 & 646.288 & 3 \\
\hline 63. & QEEL & $\beta-\mathrm{CN}(3-6)$ & 517.2 & 517.246 & 1,3 \\
\hline 64. & NVVGET & $\beta-\mathrm{CN}(7-12)$ & 697.2 & 697.276 & 6 \\
\hline 65. & VVGET & $\beta-\mathrm{CN}(8-12)$ & 503.2 & 583.233 & 3 \\
\hline 66. & ITHINK & $\beta-\mathrm{CN}(23-28)$ & 724.4 & 724.433 & 6 \\
\hline 67. & HINK & $\beta-\mathrm{CN}(25-28)$ & 510.3 & 510.299 & 7,8 \\
\hline 68. & HINKK & $\beta$-CN $(25-29)$ & 638.3 & 638.394 & 7 \\
\hline 69. & KIEK & $\beta-\mathrm{CN}(29-32)$ & 516.3 & 516.334 & $3,4,6$ \\
\hline 70. & IEKF & $\beta$-CN (30-33) & 535.3 & 535.308 & 7 \\
\hline 71. & LQDK & $\beta-\mathrm{CN}(45-48)$ & 502.3 & 502.282 & 3 \\
\hline 72. & DKIHP & $\beta-\mathrm{CN}(47-51)$ & 608.3 & 608.335 & $2,3,4,6,7,8,9$ \\
\hline 73. & DKIHPF & $\beta-\mathrm{CN}(47-52)$ & 755.4 & 755.404 & $4,7,8,9,10$ \\
\hline 74. & FTGPIPN & $\beta-\mathrm{CN}(62-68)$ & 744.3 & 744.388 & 8 \\
\hline 75. & TGPIP & $\beta-\mathrm{CN}(63-67)$ & 483.3 & 483.277 & 3 \\
\hline 76. & TGPIPN & $\beta-\mathrm{CN}(63-68)$ & 597.3 & 597.32 & $1,3,4,6,7,8,9$ \\
\hline 77. & GPIPN & $\beta-\mathrm{CN}(64-68)$ & 496.2 & 496.272 & 4 \\
\hline 78. & PQN & $\beta-\mathrm{CN}(71-73)$ & 357.1 & 357.172 & 6 \\
\hline 79. & TPVVVPP & $\beta$-CN $(80-86)$ & 707.4 & 707.429 & $3,6,8$ \\
\hline 80. & PVVVPP & $\beta-\mathrm{CN}(81-86)$ & 606.3 & 606.381 & 8 \\
\hline 81. & VVVPP & $\beta$-CN $(82-86)$ & 509.3 & 509.329 & $3,6,8$ \\
\hline 82. & VVVPPF & $\beta-\mathrm{CN}(82-87)$ & 656.3 & 656.397 & 8 \\
\hline 83. & VPPF & $\beta-\mathrm{CN}(84-87)$ & 458.3 & 458.263 & $2,4,7,8,9,10$ \\
\hline 84. & VPPFL & $\beta-\mathrm{CN}(84-88)$ & 571.8 & 571.344 & $4,8,9$ \\
\hline 85. & IMGVPK & $\beta-\mathrm{CN}(92-97)$ & 643.3 & 643.384 & 4,6 \\
\hline 86. & GVPKV & $\beta-\mathrm{CN}(94-98)$ & 498.3 & 498.324 & 7 \\
\hline 87. & VPKVK & $\beta-\mathrm{CN}(95-99)$ & 569.3 & 569.397 & 4 \\
\hline 88. & KVKE & $\beta$-CN $(97-100)$ & 502.3 & 502.319 & 6,8 \\
\hline 89. & PFPKY & $\beta-\mathrm{CN}(110-114)$ & 650.4 & 650.354 & 4 \\
\hline 90. & LPPT & $\beta-\mathrm{CN}(151-154)$ & 426.3 & 426.255 & 8 \\
\hline 91. & PQSVL & $\beta-\mathrm{CN}(159-163)$ & 542.3 & 542.314 & 3 \\
\hline 92. & PIQA & $\beta-\mathrm{CN}(184-187)$ & 427.3 & 427.254 & 3 \\
\hline 93. & YQEP & $\beta-\mathrm{CN}(191-194)$ & 535.2 & 535.235 & 3 \\
\hline 94. & PVLGP & $\beta-\mathrm{CN}(194-198)$ & 481.3 & 481.297 & $6,7,8$ \\
\hline 95. & VLGP & $\beta-\mathrm{CN}(195-198)$ & 384.3 & 384.245 & 7 \\
\hline 96. & GPVRGPFP & $\beta-\mathrm{CN}(197-204)$ & 825.4 & 825.457 & 4,7 \\
\hline 97. & GPVR & $\beta-\mathrm{CN}(197-200)$ & 427.3 & 427.262 & 4,8 \\
\hline 98. & VRGP & $\beta-\mathrm{CN}(199-202)$ & 427.8 & 427.262 & 7 \\
\hline 99. & VRGPFP & $\beta-\mathrm{CN}(199-204)$ & 671.3 & 671.383 & 7 \\
\hline 100. & RGPFPI & $\beta-\mathrm{CN}(200-205)$ & 687.4 & 685.398 & 7 \\
\hline 101. & GPFP & $\beta-\mathrm{CN}(201-204)$ & 416.2 & 416.213 & 9 \\
\hline 102. & GPFPI & $\beta-\mathrm{CN}(201-205)$ & 529.3 & 529.297 & 8 \\
\hline \multicolumn{6}{|c|}{ Different CN } \\
\hline 103. & $\mathrm{RP} / \mathrm{PR}$ & $\begin{array}{l}\alpha_{\mathrm{S} 1}-\mathrm{CN}(1-2) ; \alpha_{\mathrm{S} 2}-\mathrm{CN}(31-32) ; \\
\text { p- } \kappa-\mathrm{CN}(46-47)\end{array}$ & 271.1 & 271.172 & 7,9 \\
\hline 104. & $\mathrm{QP} / \mathrm{PQ} / \mathrm{PK}$ & $\begin{array}{l}\text { Various fragments }\left(\alpha_{\mathrm{S1}^{-}}, \alpha_{\mathrm{S} 2^{-}},\right. \\
\beta-, \text { and } \kappa-\mathrm{CN})\end{array}$ & 243.1 & 243.129 & $4,6,8$ \\
\hline 105. & $\mathrm{RF}$ & $\alpha_{\mathrm{S} 1}-\mathrm{CN}(22-23) ; \kappa-\mathrm{CN}(16-17)$ & 321.1 & 321.187 & 5 \\
\hline 106. & RL & $\alpha_{\mathrm{S} 1}-\mathrm{CN}(100-101) ; \alpha_{\mathrm{S} 2}-\mathrm{CN}(161-162)$ & 287.2 & 287.203 & 4 \\
\hline 107. & YP & $\begin{array}{c}\alpha_{\mathrm{S} 1}-\mathrm{CN}(151-152) ; \beta-\mathrm{CN}(60-61) ; \\
\beta-\mathrm{CN}(114-115) ; \kappa-\mathrm{CN}(35-36)\end{array}$ & 278.1 & 278.134 & 6 \\
\hline
\end{tabular}

${ }^{1}$ Identification of fractions: 1 = fraction 1 artisan cheese, 4 mo old; $2=$ fraction 2 artisan cheese, 4 mo old; 3 = fraction 1 artisan cheese, 8 mo old; 4 = fraction 2 artisan cheese, 8 mo old; 5 = fraction 3 artisan cheese, 8 mo old; 6 = fraction 1 industrial cheese, 4 mo old; 7 = fraction 2 industrial cheese, 4 mo old; $8=$ fraction 1 industrial cheese, 8 mo old; 9 = fraction 2 industrial cheese, 8 mo old; 10 = fraction 3 industrial cheese, 8 mo old.

subjects to conduct sensory analyses. They were trained to recognize the basic tastes with standard solutions (salty, umami, astringent, sour, sweet, and bitter) prepared in mineral water according to Molina et al. (1999). These solutions were presented to the panelists as such and in mixtures, and the results were discussed among them. Before each session, panelists tasted the reference solutions to memorize their tastes 
and intensities. They were then requested to assess the taste of the gel-permeation fractions of the WSE $<1,000 \mathrm{Da}$. The fractions were lyophilized before reconstitution with $2 \mathrm{~mL}$ of mineral water. Aliquots were placed directly onto panelists' tongues. The presence and intensity of each basic taste was evaluated on a scale ranging from 0 to 100 . As a reference, the taste intensity scores of the standard solutions were taken as 80 .

\section{RESULTS AND DISCUSSION}

\section{Peptide Identification by RP-HPLC-MS/MS}

The 5 GPC fractions obtained from the WSE $<1,000$ Da were analyzed by RP-HPLC coupled online to a mass spectrometer with the aim of identifying the peptides responsible for the taste of artisan and industrial Manchego cheeses. Identification of peptide components in complex protein hydrolysates (e.g., cheese) requires more information than just the masses of the peptides. However, unlike de novo peptide sequencing, a complete sequencing of the peptide components is not always necessary because the sequences of the precursor proteins are known. In our case, the identification approach involved searching for the masses and partial sequences (sequences tags) in a database of ovine milk proteins, including sequence modifications caused by genetic variants and posttranslational modifications (phosphorylation and glycosylation). In a second step, the MS/MS spectrum of the target peptide was compared with the MS/MS spectra of the peptides selected in the database having the same molecular weight. In most cases, the MS/MS spectrum unambiguously matched one sequence of the group of peptides selected by mass. This ideal situation would occur if the fragmentation process could be controlled so that each peptide was cleaved between every 2 consecutive AA and a single charge was retained on the $\mathrm{N}$-terminal group. However, the fragmentation process in mass spectrometers is far from ideal, and some peptides exhibited fragmentation patterns that deviated significantly from the expected fragmentation pattern, and these had to be identified manually.

A total of 107 different peptides were identified in the different fractions of artisan or industrial Manchego cheese at 4 and 8 mo of ripening. Table 1 shows the sequences, protein fragments, CN of origin, and observed and calculated masses of the peptides identified by MS/MS in the different GPC fractions of Manchego cheeses. Peptides were mainly detected in fractions 1 and 2 . In fraction 3 only a few peptides were identified, all of them found in cheeses at $8 \mathrm{mo}$ of ripening. No peptides were detected in fractions 4 and 5 . These results agree with those of Fernández et al.
(1998), who analyzed the WSE of Cheddar cheese by GPC. Those authors also found the peptides concentrated in the first eluting fractions, a full range of AA in the middle eluting fractions, and Phe, Tyr, and Trp in the last eluting fractions.

All peptides were unequivocally identified, except in the case of INEL/LNEI, for which it was not possible to differentiate between the 2 isomeric AA Leu and Ile. The presence of both residues in the studied peptide prevented us from using MS/MS spectra of the $\mathrm{m} / \mathrm{z} 86$ immonium ions of Leu or Ile residues. In addition, the $\mathrm{w}$ - and $\mathrm{d}$-series daughter ions were not sufficiently strong to use as a tool to distinguish both residues. Peptides originating from $\alpha_{\mathrm{S} 1}$-CN dominated the degradation products, with 50 peptides arising from this protein. Ten of the identified peptides corresponded to $\alpha_{\mathrm{S} 2}-\mathrm{CN}$ fragments, and 42 to $\beta$-CN fragments. No peptides were found derived from $\mathrm{p}-\kappa-\mathrm{CN}$. Several dipeptides (103 to 107 in Table 1) were also identified. The AA sequence of these dipeptides was identified in several CN; therefore, they may have their origin in different $\mathrm{CN}$ fractions. The highest number of peptides was identified in artisan cheeses. These cheeses usually show a higher proteolysis because they are elaborated with raw milk. In fractions 1 and 2 of the artisan Manchego cheese at 8 mo of ripening, 66 peptides were identified, whereas 38 peptides were identified only in industrial cheeses with the same ripening time. Several peptides (EIVPK, DKIHP, TGPIPN) were identified in 7 of the 8 analyzed fractions. Most of these peptides are described for the first time in Manchego cheese. Among the 107 identified peptides, only 15 had previously been reported in this type of cheese, in a study on the identification and formation of angiotensin I-converting enzyme inhibitory peptides (GómezRuiz et al., 2002b, 2004). Peptides 2, 4, 5, 7, 16, 19, 21 , and 24 from $\alpha_{\mathrm{S1}}-\mathrm{CN}$ and 77 and 98 (Table 1) from $\beta$-CN have been identified in Emmental juice (Gagnaire et al., 2001). Additionally, peptides with the same AA sequence as peptides $16,18,20$, and 33 derived from $\alpha_{\mathrm{S} 1}-\mathrm{CN}$ have previously been reported in Cheddar cheese (Alli et al., 1998; Fernández et al., 1998).

\section{Contribution of Peptides to the Umami and Bitter Tastes in Manchego Cheese}

The sensory evaluation of GPC fractions 1 to 3 of artisan and industrial milk cheeses at 4 and 8 mo of ripening showed that in both types of cheeses, umami was the predominant taste in all fractions, followed by salty and bitter. The salty taste is usually attributed to the presence of greater amounts of salts rather than to the presence of specific peptides (Molina et al., 1999). 
Table 2. Scores for umami and bitter tastes and possible peptides and AA responsible for such tastes in the Sephadex G-10 gel-permeation fractions 1 to 3 from the water-soluble extract with a molecular weight $<1,000 \mathrm{Da}$ of raw and pasteurized Manchego cheeses after 4 and 8 mo of ripening ${ }^{1}$

\begin{tabular}{|c|c|c|c|c|c|c|c|c|c|}
\hline \multirow[b]{2}{*}{ Taste } & \multirow[b]{2}{*}{ Fraction } & \multicolumn{4}{|c|}{ Raw milk cheese } & \multicolumn{4}{|c|}{ Pasteurized milk cheese } \\
\hline & & Score & Peptide & Score & Peptide & Score & Peptide & Score & Peptide \\
\hline \multirow[t]{3}{*}{ Umami } & 1 & 42 & $\begin{array}{l}\text { ENINEL, INEL, } \\
\text { PSE, QEEL }\end{array}$ & 43 & $\begin{array}{l}\text { INEL, PSE, LEQL, } \\
\text { EQEEL, QEEL }\end{array}$ & 40 & $\begin{array}{l}\text { RKE, INEL, } \\
\text { SAEQK, NVVGET }\end{array}$ & 37 & $\begin{array}{l}\text { ENINEL, INEL, } \\
\text { VVGET }\end{array}$ \\
\hline & 2 & 44 & $*$ & 65 & INEL & 47 & * & 38 & $*$ \\
\hline & 3 & 40 & $*$ & 30 & $*$ & 29 & * & 20 & * \\
\hline \multirow{2}{*}{ Bitter } & 2 & 48 & $\bullet$ & ND & $\begin{array}{l}\text { VVAPFP, VAPFP, } \\
\text { APFPE, VPPFL, } \\
\text { PFPKY, GPVRGPFP }\end{array}$ & - & $\begin{array}{l}\text { VVAPFPE, APFPE, } \\
\text { GPVRGPFP, VRGPFP, } \\
\text { RGPFPI }\end{array}$ & - & VPPFL, GPFPI \\
\hline & 3 & 40 & Tyr & 3 & Phe, Tyr & 8 & Phe, Tyr & - & Phe, Tyr \\
\hline
\end{tabular}

${ }^{1}$ An asterisk (*) indicates no umami peptides were identified; a minus (-) indicates the taste was not detected; a bullet (-) indicates no bitter peptides were identified.

Astringent and sour tastes were detected slightly, and the sweet taste was absent. In general, the scores for the intensity of the tastes were higher for artisan cheeses than for industrial cheeses. Gómez-Ruiz et al. (2002a) found that Manchego cheeses made from raw milk had a more complex volatile profile and odor intensities than their pasteurized milk counterparts throughout ripening.

Consequently, only peptide sequences related to the umami and bitter tastes were investigated among the different peptides identified in the RP-HPLC-MS/MS analysis. Taste-active peptides and the scores for the umami and bitter tastes given by the panelists are shown in Table 2.

Different umami peptides were found in fractions 1 and 2 of all cheese samples (Table 2). The high scores for umami taste in these fractions may be due to the presence of such umami peptides. The pair Glu-Glu (EE) has previously been reported as an umami peptide (with a taste by itself) in synthetic form (Maehashi et al., 1999) and in fish hydrolysates (Noguchi et al., 1975). In our study, a peptide containing EE in its sequence (QEEL, $\beta$-CN) was found in fraction 1 of artisan cheeses at 4 and 8 mo of ripening. However the highest umami intensity was found in fraction 2 of 8mo-old artisan cheeses, in which only the peptide INEL was identified. Hence, it is possible that some other peptides contribute to the umami taste described in this fraction, because the peptide INEL was also identified in fraction 1 , in which the umami taste was perceived with less intensity. In addition, other compounds, such as free AA, are capable of giving an umami taste. Glutamic acid has been reported to be the predominant $\mathrm{AA}$ in fraction 1 of ovine milk cheeses (Molina et al., 1999), and Taborda (unpublished re- sults) found that Glu and Asp were the main free AA in fraction 1 (accounting for 90 to $100 \%$ of the total free AA). Therefore, the umami taste of fractions 1 and 2 may be due to umami-active peptides or to free Glu and Asp residues. Moreover, Maehashi et al. (1999) showed that many umami peptides did not have an umami taste per se, although their combination with $0.02 \% 5$ '-inosine monophosphate produced a delicious, "full" umami taste.

No umami peptides were found in fraction 3. However, RP-HPLC-MS/MS analysis identified the ammonium ions of Phe (except in 4-mo-old artisan cheese) and Tyr (except in 8-mo-old industrial cheese). These AA are retarded in GPC because of hydrophobic interactions, so they were expected in fraction 4 or 5 . However, it should be noted that pure water was used as the eluent to allow sensory analysis; therefore, the separation was not based on molecular size alone. Both aromatic AA showed a significant umami-enhancing effect on the umami taste of monosodium glutamate$\mathrm{NaCl}$ mixtures. This is a novel phenomenon for the so-called bitter AA (Lioe et al., 2005).

Regarding bitterness, it is generally accepted as a consequence of CN degradation (Lemieux and Simard, 1992). Using omissions tests to determine taste-active compounds of Camembert cheese, Engel et al. (2001) showed that peptides were the major contributors to the bitter taste, although the bitterness of Camembert was due not only to its chemical properties but also to the chemical environment and $\mathrm{pH}$ at which it was tasted. Moreover, Kim and Li-Chan (2006) recently showed that bulky hydrophobic AA at the $\mathrm{C}$ terminus and bulky basic AA at the $\mathrm{N}$ terminus were highly correlated with bitterness. In our study, no relation between peptides and bitterness was established (Ta- 
ble 2), although the selected peptides joined the characteristics of bitterness described previously. The peptide RGPFPI, found in fraction 2 of industrial cheeses at 8 mo of ripening, did not lead to any bitter taste, as perceived by the judges, although the heptapeptide RGPFPIV had a high bitterness intensity (Kim and Li-Chan, 2006). Probably, the independent sensory evaluation of the subfractions of the WSE did not take into account complex taste interactions that may exist among those subfractions in the crude WSE. Peptides are not systematically responsible for cheese bitterness, and some compounds involved in other taste characteristics may disturb the perception of bitter stimuli (Engel et al., 2000).

The taste of peptides by themselves is discussed controversially in the literature, including studies reporting that the "delicious" beefy meaty peptide does not have any umami or other taste (van Wassenaar et al., 1995; Hau et al., 1997). The individual taste of most peptides is probably weak or even undetectable, and their role in eliciting an intense umami taste remains unclear. In our study, the umami taste was predominant in all fractions, even in those in which umami-tasting peptides were not found. Therefore, it is difficult to understand the real impact of peptides on the umami properties of the WSE $<1,000 \mathrm{Da}$ of Manchego cheese. In a study on soy sauces, Lioe et al. (2006) concluded that peptides, especially those containing glutamyl residues, did not contribute significantly to the umami taste of koikuchi and tamari shoyu. In addition, those peptides with a taste similar to that of monosodium glutamate or umami peptides are known to have the property of masking the taste of foods (Ohyama et al., 1988), so other tastes of the fractions could be underestimated, and this could be the reason for the predominant umami taste in all fractions. These results are in agreement with those reported by Salles et al. (2000) in the evaluation of taste compounds in WSF of goat cheeses, in which the direct impact of the low molecular weight compounds on the taste of cheeses was minimized. However, the same group reported that the omission of peptides and AA in a model WSE led to a significant decrease in the umami taste (Engel et al., 2001).

In our study, the high scores for umami taste in fraction 1 of artisan cheeses at 4 and 8 mo of ripening could be attributed to the peptides EQEEL and QEEL, which contain a high number of glutamic residues. Furthermore, the presence of salts could be important in enhancing the flavor peptides, and other mentioned factors, such as interactions among peptides, the presence of new peptides still not evaluated sensorially, and free and conjugated AA, can have an influence on the overall taste.

\section{ACKNOWLEDGMENTS}

This work was financially supported by the projects AGL2005-03381 from the Spanish Ministry of Education and Science (MEC) and S-505/AGR/0153-01 from the Autonomous Community of Madrid. G. Taborda wishes to express his appreciation to the University of Caldas and Colciencias (Colombia) for the financial fellowship.

\section{REFERENCES}

Alli, I., M. Okoniewska, B. F. Gibbs, and Y. Konishi. 1998. Identification of peptides in Cheddar cheese by electrospray ionization mass spectrometry. Int. Dairy J. 8:643-649.

Careri, A., and A. Mangia. 2003. Analysis of food proteins and peptides by chromatography and mass spectrometry. J. Chromatogr. A 1000:609-635.

Engel, E., S. Nicklaus, C. Septier, C. Salles, and J. L. Le Queré. 2000. Taste-active compounds in a goat cheese water-soluble extract. 2. Determination of the relative impact of water-soluble extract components on its taste using omission tests. J. Agric. Food Chem. 48:4260-4267.

Engel, E., C. Septier, N. Leconte, C. Salles, and J. L. Le Queré. 2001. Determination of taste-active compounds of a bitter Camembert cheese by omission tests. J. Dairy Res. 68:675-688.

Engels, W. J. M., and S. Visser. 1994. Isolation and comparative characterization of components that contribute to the flavor of different types of cheese. Neth. Milk Dairy J. 48:127-140.

Fernández, M., T. K. Singh, and P. F. Fox. 1998. Isolation and identification of peptides from the diafiltration permeate of the water-soluble fraction of Cheddar cheese. J. Agric. Food Chem. 46:4512-4517.

Fernández-García, E., M. Carbonell, and M. Núñez. 2002. Volatile fraction and sensory characteristics of Manchego cheese. 1. Comparison of raw and pasteurized milk cheese. J. Dairy Res. 69:579-593.

Gagnaire, V., D. Molle, M. Herrouin, and J. Léonil. 2001. Peptides identified during Emmental cheese ripening: Origin and proteolytic systems involved. J. Agric. Food Chem. 49:4402-4413.

Gómez-Ruiz, J. A., C. Ballesteros, M. A. Gonzalez-Viñas, L. Cabezas, and I. Martínez-Castro. 2002a. Relationship between volatile compounds and odor in Manchego cheese: Comparison between artisanal and industrial cheeses at different ripening times. Lait 82:613-628.

Gómez-Ruiz, J. A., M. Ramos, and I. Recio. 2002b. Angiotensinconverting enzyme-inhibitory peptides in Manchego cheeses manufactured with different starter cultures. Int. Dairy J. 12:697-706.

Gómez-Ruiz, J. A., M. Ramos, and I. Recio. 2004. Identification and formation of angiotensin-converting enzyme-inhibitory peptides in Manchego cheese by high-performance liquid chromatography-tandem mass spectrometry. J. Chromatogr. A 1054:269 277.

Gómez-Ruiz, J. A., G. Taborda, L. Amigo, I. Recio, and M. Ramos. 2006. Identification of ACE-inhibitory peptides in different Spanish cheeses by tandem mass spectrometry. Eur. Food Res. Technol. 223:595-601.

González-Viñas, M. A., J. M. Poveda, A. García-Ruiz, and L. Cabezas. 2001. Changes in chemical, sensory and rheological characteristics of Manchego cheeses during ripening. J. Sens. Stud. 16:361-371.

Hau, J., D. Cazes, and L. B. Fay. 1997. Comprehensive study of the "beefy meaty peptide." J. Agric. Food Chem. 45:1351-1355.

Kim, H.-O., and E. C. Y. Li-Chan. 2006. Quantitative structureactivity relationship study of bitter peptides. J. Agric. Food Chem. 54:10102-10111.

Lemieux, L., and R. E. Simard. 1992. Bitter flavor in dairy products. II. A review of bitter peptides from the caseins: Their formation, 
isolation, identification, structure masking and inhibition. Lait 72:335-382.

Lioe, H. N., A. Apriyantono, K. Takara, K. Wada, and M. Yasuda. 2005. Umami taste enhancement of MSG/NaCl mixtures by subthreshold L- $\alpha$-aromatic amino acids. J. Food Sci. 70(7):S401S405.

Lioe, H. N., K. Takara, and M. Yasuda. 2006. Evaluation of peptide contribution to the intense umami taste of Japanese soy sauces. J. Food Sci. 71:S277-S283.

Maehashi, K., M. Matsuzaki, Y. Yamamoto, and S. Udaka. 1999. Isolation of peptides from an enzymatic hydrolysate of food proteins and characterization of their taste properties. Biosci. Biotechnol. Biochem. 63:555-559.

McSweeney, P. L. H. 1997. The flavour of milk and dairy products: III. Cheese: Taste. Int. J. Dairy Technol. 50:123-128.

Molina, E., M. Ramos, L. Alonso, and R. López-Fandiño. 1999. Contribution of low molecular weight water soluble compounds to the taste of cheeses made of cows', ewes' and goats' milk. Int. Dairy J. 9:613-621.

Noguchi, M., S. Arai, M. Yamashita, H. Kato, and M. Fujimaki. 1975. Isolation and identification of acidic oligopeptides occurring in a flavor potentiation fraction from a dish protein hydrolysate. J. Agric. Food Chem. 23:49-53.

Ohyama, S., N. Ishibashi, M. Tamura, H. Nishizaki, and H. Okay. 1988. Studies on flavored peptides. 6 . Synthesis of bitter peptides composed of aspartic-acid and glutamic-acid. Agric. Biol. Chem. $52: 871-872$

Polo, M. C., M. Ramos, and D. González de Llano. 2000. HPLC of peptides. Pages 99-125 in Food Analysis by HPLC. 2nd ed. L. M. L. Nollet, ed. Marcel Dekker, New York, NY.

Roudot-Algaron, F. 1996. Le goût des acides aminés, des peptides et des protéines: Exemple de peptides sapides dans les hydrolysates de caséines. Lait 76:313-348.

Salles, C., C. Hervé, C. Septier, D. Demaizières, I. Lesschaeve, S. Issanchou, and J. L. Le Queré. 2000. Evaluation of taste compounds in water-soluble extract of goat cheese. Food Chem. 68:429-435

Salles, C., C. Septier, F. Roudot-Algaron, A. Guillot, and P. X. Etiévant. 1995. Sensory and chemical analysis of fraction obtained by gel permeation of water-soluble Comté cheese extracts. J. Agric. Food Chem. 43:1659-1668.

Taborda, G. 2001. Flavor compounds of the water soluble fraction of Manchego cheese. Amino acid catabolism. PhD Thesis. Faculty of Science, Autonomous University of Madrid, Spain.

Taborda, G., E. Molina, I. Martínez-Castro, M. Ramos, and L. Amigo. 2003. Composition of the water-soluble fraction of different cheeses. J. Agric. Food Chem. 51:270-276.

van Wassenaar, P. D., A. H. A. van der Oord, and W. M. M. Schaaper 1995. Taste of "delicious" beefy meaty peptide. Revised. J. Agric. Food Chem. 43:2828-2832. 